\title{
ANALISIS PIUTANG TAK TERTAGIH DAN DAMPAKNYA TERHADAP LAPORAN KEUANGAN PADA PT BANK RAKYAT INDONESIA (PERSERO) TBK CABANG MANADO
}

\author{
Grace Gloria P. Tampi ${ }^{1}$, Inggriani Elim², Meily Y.B Kalalo ${ }^{3}$ \\ ${ }^{1,2,3}$ Fakultas Ekonomi dan Bisnis, Jurusan Akuntansi, Universitas Sam Ratulangi, Jl. Kampus Bahu, Manado, \\ 95115, Indonesia \\ E-mail : gracegloriatampi@gmail.com
}

\begin{abstract}
This study aims to determine the impact of the uncollectible receivables on financial statements at PT Bank Rakyat Indonesia (Persero) Tbk Manado Branch. Bad debts are generally loans whose principal installments have passed 91 days from the due date. This study uses a qualitative method. This research was conducted by interviewing the Operations Manager, Marketing Manager, and Credit Section Staff of PT. Bank Rakyat Indonesia (Persero) Tbk Manado Branch. The research obtained results that show the impact of uncollectible receivables affects the financial statements. Thus, the bank calculates the age receivable reserve to determine the amounts of credit provided and determine the amounst of allowance for uncollectible accounts.
\end{abstract}

Keywords: Receivable; uncollectible receivables; financial reports; reserves of uncollectible accounts; the allowance method

\section{PENDAHULUAN}

Peran bank dalam mengembangkan perekonomian suatu Negara sekarang ini sangatlah penting. Hampir semua pihak atau sektor yang berhubungan dengan beragam kegiatan keuangan selalu membutuhkan jasa perbankan (Sumarauw dan Gerungai 2018). Dalam aktivitas perbankan, adanya kegiatan pinjam meminjam sejumlah uang merupakan suatu kegiatan yang selalu saja dilakukan. Praktek pinjam meminjam dalam sistem perbankan mengakibatkan timbulnya pihak yang memberi pinjaman (kreditor), yaitu bank dan pihak yang menerima pinjaman (debitor), yaitu nasabah.

Dalam pemberian kredit kepada nasabah, bank juga harus siap menghadapi berbagai resiko yang akan terjadi. Sebelum pihak bank mengadakan penyaluran kredit terhadap nasabah, ada beberapa prinsip kehati-hatian yang harus dilakukan pihak bank melalui analisa yang akurat dan mendalam, adanya pengawasan dan pemantauan, adanya perjanjian yang sah antara pihak pemberi pinjaman dan yang menerima pinjaman, harus memenuhi syarat hukum, adanya jaminan yang kuat dan dokumentasi perkreditan. Hal ini bertujuan untuk menghindari berbagai resiko yang mungkin dapat terjadi dalam proses pinjam meminjam. Akan tetapi secara teknis, banyak faktor tak diduga yang menyababkan pembayaran kredit dari pihak peminjam jadi terhambat atau macet, seperti karena kebangkrutan, kebijakan pemerintah dan beberapa faktor lainnya yang tidak dapat dikendalikan baik dari pihak bank ataupun dari pihak debitur seperti bencana alam.

Pinjaman yang tidak dapat dikembalikan oleh pihak peminjam atau debitu ini yang kemudian akan disebut sebagai piutang tak tertagih. Hal ini menyebabkan setiap rupiah yang pinjamkan atau disalurkan, memiliki kemungkinan untuk tidak kembali. Kejadian seperti ini sangat berdampak pada penyajian laporan keuangan. Karena laporan keuangan merupakan salah satu dasar penting dalam menilai keadaan finansial dari suatu perusahaan serta menimbulkan aspek-aspek lainnya yang berhubungan dengan perusahaan. Kredit merupakan salah satu indikator penting dalam keberhasilan suatu bank. Dimana penyaluran kredit PT. 
Bank Rakyat Indonesia dari tahun 2015, tahun 2016, dan tahun 2017 dalam hal ini terdapat dalam fasilitas kredit KUR (Kredit Usaha Rakyat) dan KUPEDES (Kredit Usaha Pedesaan) yang total kreditnya mengalami peningkatan yang kemudian menjadi persoalan penting bagi perbankan.

\section{TINJAUAN PUSTAKA}

Konsep akuntansi. Akuntansi dapat diartikan dari dua sudut pandang yaitu dari sudut pemakai jasa akuntansi dan dari sudut pandang kegiatannya. Dilihat dari sudut pandang pemakai akuntansi dapat artikan bahwa akuntansi merupakan ilmu yang menyediakan informasi seperti laporan keuangan yang diperlukan oleh pihak-pihak yang terlibat langsung pada kegiatan ekonomi dan kondisi perusahaan (Pujiyanti, 2015:19). Akuntansi meliputi proses pelaporan, pengidentifikasian transaksi, pencatatan, pengkomunikasian (dalam bentuk laporan), sampai pada tahap analisis (Hery, 2013:8).

Akuntansi keuangan. Akuntansi keuangan merupakan bagian dari akuntansi yang menyiapkan laporan keuangan untuk pihak eksternal, seperti para pemegang saham, kreditor, pemasok, dan pemerintah. Akuntansi keuangan berhubungan dengan masalah pencatatan transaksi dan penyusunan berbagai laporan berkala dari hasil pencatatan transaksi tersebut. Akuntansi keuangan adalah bagian dari akuntansi yang menyediakan berbagai informasi mengenai ekonomi dan keuangan kepada investor, kreditor, dan pengguna luar lainnya (Weygant et al., 2015:6).

Konsep piutang. Fahmi (2016:137) mengemukakan pendapat mengenai piutang yang merupakan bentuk penjualan secara kredit atau pembayarannya tidak dilakukan secara tunai. Pontoh (2013:287) menyatakan piutang adalah sebuah proses penagihan atas sejumlah uang tunai di masa yang akan datang yang disebabkan karena adanya transaksi yang terjadi di masa kini. Hery (2014:29) menyatakan piutang timbul dari adanya penjualan barang atau jasa secara kredit kepada pelanggan.

Piutang tak tertagih. Hery (2014:186) piutang tak tertagih terjadi karena adanya pelanggan yang tidak bisa membayar kewajibannya karena mengalami penurunan perekonomian dan kebangkrutan dari pihak debitur.

Faktor-faktor piutang tak tertagih. Menurut Rivai et al., (2013:238-239), kredit macet atau piutang tak tertagih dapat terjadi atau disebabkan oleh beberapa faktor, yaitu faktor internal yang berasal dari pihak pemberi pinjaman dan Faktor Eksternal atau pihak yang menerima pinjaman.

Perhitungan kerugian piutang tak tertagih. Dikutip dari Demak (2018), menurut Hery perhitungan yang menggunakan metode cadangan setiap akhir periode akan dilakukannya perhitungan jumlah kerugian piutang yang akan dibebankan ke periode tersebut. Dalam hal ini ada beberapa cara yang dapat digunakan untuk menentukan atau mengetahui kerugian piutang, yaitu Persentase dari jumlah penjualan atau juga disebut sebagai metode laba rugi. Metode ini digunakan untuk besarnya estimasi beban kredit macet. Adapun cara yang di lakukan, yaitu Persentasi dari jumlah piutang usaha yang kemudian akan dilaporkan dalam neraca. Ada dua metode yang dibagi dalam cara ini, yaitu berdasarkan jumlah saldo akhir piutang dan berdasarkan pengelompokkan umur piutang.

Metode Pencatatan Piutang Tak Tertagih. Menurut Mardiasmo (2016: 52-53) perlakuan akuntansi terhadap penghapusan piutang terdapat dua metode, yaitu Metode Penghapusan Langsung dan Metode Cadangan.

Kualitas kredit. Menurut Rivai et al., (2013:211) hal utama untuk menentukan kualitas kredit adalah waktu pembayaran bunga, angsuran, maupun pembayaran pokok pinjaman. Adapun kategorinya, yaitu Kredit Lancar 0 hari, Perhatian Khusus 1-90 hari, Kurang Lancar 91-180 hari, Diragukan 180-270 hari, Macet lebih dari 270 hari. 
Konsep laporan keuangan. Menurut Ikatan Akuntansi Indonesia PSAK No.1 (2015:2) Laporan keuangan merupakan catatan informasi keuangan sebuah perusahaan atau instansi terkait. Laporan keuangan tersebut terdiri dari laporan neraca, laporan laba rugi, laporan perubahan posisi keuangan, catatan dan laporan lainnya. Semua laporan harus dicantumkan agar laporan keuangan disajikan secara lengkap. Laporan keuangan juga digunakan sebagai patokan kinerja sebuah perusahaan atau instansi terkait. Menurut Junita dan Khairani (2012) yang dimaksud dengan laporan keuangan, yaitu ringkasan hasil akhir dari proses akuntansi yang berisi mengenai transaksi keuangan dari perusahaan bersangkutan yang kemudia diolah sehingga dapat bermanfaat untuk melihat dan memberikan informasi bagaimana keadaan finansial perusahaan tersebut yang selanjutnya dapat digunakan bagi pihak yang membutuhkan. Kartikahadi et al. (2016:12) menyatakan laporan keuangan di susun dengan beberapa unsur, yaitu laporan neraca, laporan laba/ rugi, laporan perubahan modal, arus kas, catatan atas laporan keuangan, dan laporan posisi keuangan awal periode.

Pengertian Bank. Menurut Undang-Undang Nomor 10 Tahun 1998 Bank adalah usaha yang menghimpun, menyimpan dan menyalurkan dana kepada masyarakat untuk kesejahteraan hidup rakyat. Menurut Kasmir (2013:24) bank adalah lembaga keuangan yang memiliki kegiatan utama, yaitu menerima simpanan giro, tabungan dan deposit. Kegiatan lainnya dari bank adalah sebagai tempat meminjam, menukar dan memindahkan sejumlah uang serta dapat pula menerima segala bentuk pembayaran dan setoran.

\section{METODE PENELITIAN}

\subsection{Jenis dan sumber data}

Jenis data. Jenis data yang di gunakan, yaitu data kulitatif berupa hasil wawancara, sejarah perusahaan, visi dan misi, serta struktur organisasi. Dan data kulitatif yang berupa susunan angka-angka dalam hal ini laporan keuangan dan daftar posisi piutang tak tertagih.

Sumber data. Sumber data yang digunakan dalam penelitian ini adalah data primer, yaitu Laporan Keuangan Neraca dan Daftar Posisi Piutang Pada Akhir Periode. Dan yang menjadi sumber pengambilan data penelitian adalah PT. Bank Rakyat Indonesia (Persero), Tbk. Cabang Manado.

\subsection{Metode analisis}

Metode pengumpulan data yang dilakukan dalam penelitian ini, yaitu:

1. Wawancara. Proses memperoleh penjelasan dengan mengadakan tanya jawab langsung kepada pihak yang terkait dalam instansi perbankan dalam hal ini Manager Operasional, Staf Bagian Kredit dan Manager Pemasaran. Metode ini digunakan untuk memperoleh data mengenai gambaran umum perhitungan dan pencatatan piutang tak tertagih, kebijakan piutang tak tertagih serta bagaimana dampak piutang tak tertagih terhadap laporan keuangan yang terdapat pada PT. Bank Rakyat Indonesia (Persero) Tbk Cabang Manado.

2. Dokumentasi. Adapun dokumen yang dikumpulkan dalam proses penelitian pada PT. Bank Rakyat Indonesia Cabang Manado seperti: (a) laporan Keuangan dalam hal ini Laporan Neraca PT. Bank Rakyat Indonesia (Persero) Tbk Cabang Manado tahun 20152017; dan (b) daftar Posisi Piutang Pada Akhir Periode PT. Bank Rakyat Indonesia Cabang (Persero) Tbk Cabang Manado tahun 2015-2017.

Proses Analisis yang dilakukan dalam penelitian ini, yaitu :

1. Tahap pertama, mengumpulkan data mengenai perhitungan dan pencatatan piutang tak tertagih, kebijakan piutang tak tertagih, serta dampak piutang tak tertagih terhadap laporan keuangan pada PT. Bank Rakyat Indonesia (Persero) Tbk Cabang Manado.

2. Tahap kedua, setelah mengumpulkan dokumen Laporan Keuangan Neraca dan Daftar Posisi Piutang Pada Akhir Periode tahun 2015-2017 PT Bank Rakyat Indonesia (Persero) Tbk Cabang Manado. 
3. Tahap ketiga, peneliti melakukan analisis data mengenai pencatatan dan perhitungan piutang tak tertagih, kebijakan piutang tak tertagih, serta dampak piutang tak tertagih terhadap laporan keuangan. Langkah selanjutnya peneliti mengolah kemudian membahas hasil penelitian pada PT Bank Rakyat Indonesia (Pereso) Tbk Cabang Manado.

4. Tahap keempat, peneliti menarik kesimpulan dari pembahasan yang telah dilakukan pada tahap sebelumnya.

5. Tahap akhir yang dilakukan adalah peneliti akan memberikan saran jika ditemukan adanya kekurangan yang ditemukan pada PT. Bank Rakyat Indonesia (Persero) Tbk Manado.

\section{HASIL ANALISIS DAN PEMBAHASAN}

\subsection{Hasil analisis}

Faktor penyebab piutang tak tertagih. Ada beberapa fasilitas kredit yang disediakan Bank Rakyat Indonesia (Persero) Tbk Cabang Manado, seperti KUR (Kredit Usaha Rakyat), KUPEDES (Kredit Usaha Pedesaan), KKB (Kredit Kendaraan Bermotor), KPR (Kredit Pemilikan Rumah), BRIGuna. Secara teknis, ada banyak faktor yang menyebabkan pembayaran kredit dari penerima pinjaman menjadi macet. Beberapa hal yang dapat terjadi, yaitu disebabkan karena kebangkrutan, kebijakan pemerintah dan adanya faktor-faktor lain yang tidak bisa dikendalikan, seperti bencana alam. Kredit yang tidak dapat dibayar kemudian disebut piutang tak tertagih yang memungkinkan sejumlah dana yang disalurkan tidak kembali.

Perhitungan dan pencatatan piutang tak tertagih. Untuk menentukan kerugian piutang, perusahaan akan menghitung kerugian piutang dengan membuat estimasi pembentukan PPAP (Penyisihan Penghapusan Aktiva Produktif) dengan cara menentukan hari jatuh tempo sejak terjadinya pinjaman, membuat skedul umur piutang, setelah itu pihak bank menghitung besarnya cadangan piutang tak tertagih dengan cara sebagai berikut:

\section{Persentase kerugian piutang $\mathbf{x}$ saldo piutang}

Setelah terlebih dahulu ditaksir, piutang tak tertagih kemudian akan diakui sebagai biaya pada periode berjalan. Setelah dilakukannya perhitungan, pihak bank kemudian akan melakukan pencatatan dengan mencatatnya ke dalam jurnal penyesuaian berikut:
Kerugian Piutang
Rp. $x x x$
Cadangan Kerugian Piutang
Rp. $x x x$

Ketika PT Bank BRI menetapkan piutang sudah tidak dapat ditagih maka PT Bank BRI akan membuat jurnal:

$$
\text { Cadangan Kerugian Piutang Rp. } x x x
$$

Piutang Usaha

Rp. xxx

Pada saat nasabah memberitahukan bahwa piutang masih dapat dibayar, maka perusahaan akan mencatat jurnal sebagai berikut:
Piutang Usaha
Rp. $x x x$
Cadangan Kerugian Piutang
Rp. $x x x$

Pada waktu nasabah akan melakukan pembayaran, maka PT Bank BRI akan mengakuinya sebagai penerimaan, pihak Bank akan mencatat jurnal sebagai berikut:

Kas

Piutang Usaha

Rp. $x x x$

Rp. $x x x$

Penyajian piutang tak tertagih dalam laporan keuangan PT Bank Rakyat Indonesia (Persero) Tbk Cabang Manado, yaitu pertama piutang tak tertagih disajikan pada neraca (on balance sheet) apabila masih dicatat dalam pembukuan dan masih ditagih. Penyajian kedua akan disajikan pada neraca off balance sheet apabila piutang tak tertagih sudah hapus buku tapi belum hapus tagih. 
Kebijakan piutang tak tertagih. Dalam penyaluran kredit pada nasabah oleh PT Bank Rakyat Indonesia (Persero) Tbk Cabang Manado, pihak bank terlebih dahulu akan melakukan analisis dalam bentuk memo analisa dengan menerapkan $5 \mathrm{C}$, yaitu character, capacity, condition, capital, dan collateral. Hal ini dilakukan untuk dapat melihat kualitas kelayakan seorang pemohon kredit yang ditentukan perusahaan. Adapun penyaluran kredit oleh pihak bank diklasifikasikan menjadi 5 golongan, yaitu Golongan I Pinjaman Lancar, Golongan II Pinjaman Dalam Perhatian Khusus, Golongan III Pinjaman Kurang Lancar, Golongan IV Diragukan, dan Golongan V Macet. Pada klasifikasi ini Golongan I dan Golongan II merupakan angsuran yang masih dapat ditagih. Sedangkan tunggakan angsuran yang masuk Golongan III sampai Golongan V atau lebih dari 91 hari akan diakui sebagai kredit bermasalah atau piutang tak tertagih. Piutang tak tertagih ini merupakan faktor yang mempengaruhi pendapatan, maka menjadi beban dan di akui sebagai biaya piutang tak tertagih.

Dampak piutang piutang tak tertagih. Hasil akhir dari pencatatan dan penyajian piutang tak tertagih pada PT Bank Rakyat Indonesia (Persero) Tbk Cabang Manado adalah mencatatnya pada laporan keuangan perusahaan, dengan dampaknya yaitu semakin besar piutang-piutang tak tertagih, pencadangan akan semakin besar. Dan semakin besar pencadangan hal itu akan menimbulkan kerugian pada pihak bank.

\subsection{Pembahasan}

Berdasarkan dengan teori yang dikemukakan oleh Mardiasmo (2016: 52-53), bahwa metode pencatatan piutang tak tertagih terbagi atas dua metode, yaitu metode pengahapusan langsung dan metode penyisihan atau metode cadangan. Hal ini sesuai dengan hasil hasil penelitian yang telah dikemukakan pada PT Bank Rakyat Indonesia (Persero) Tbk Cabang Manado dalam hal ini perhitungannya terhadap piutang tak tertagih, PT Bank BRI menggunakan metode penyisihan atau metode cadangan dengan membuat estimasi pembentukan PPAP, yaitu mengalikan tarif persentase kerugian piutang (yang telah ditetapkan) dengan saldo piutang. Dalam hal ini jumlah piutang yang diperkirakan tak dapat ditagih dicadangkan pada akhir periode yang kemudian melakukan pencatatan dalam jurnal penyesuaian. Dan dalam pencatatannya pihak bank memiliki mekanisme penghapusan piutang tak tertagih, yaitu hapus buku tetapi tidak hapus tagih. Artinya, walaupun perusahaan sudah menghapus piutang tak tertagih, piutang tersebut akan masih tetap tertagih. Pencatatan Jurnal diatas kemudian akan di sajikan dalam laporan neraca (on balance sheet) dimana piutang tak tertagih masih dicatat dalam pembukuan dan masih ditagih dan dicatat dalam neraca off balance sheet apabila piutang tak tertagih sudah hapus buku tapi belum hapus tagih. Kemudian dicatat dalam laba/ rugi yang berfokus pada jumlah beban.

Dalam menyalurkan kredit kepada nasabah, ada beberapa kebijakan yang diterapkan pihak bank untuk dapat diperhatikan oleh calon debitur, yaitu harus memperhatikan klasifikasi pinjaman kredit yang, sebagai berikut: Lancar sebesar 1\%, yaitu kredit yang tidak memiliki tunggakan. Artinya debitur dapat membayar pinjaman setiap tanggal jatuh tempo. Dalam Perhatian Khusus sebesar 5\%, termasuk dalam penggolongan kredit yang memiliki tunggakan sampai dengan 90 hari. Kurang Lancar sebesar 15\%, terjadi apabila tunggakan debitur antara 91 hari sampai dengan 180 hari. Artinya debitur tidak dapat membayar angsuran pokok atau bunga setiap tanggal jatuh tempo. Diragukan 50\%, terjadi apabila tunggakan debitur antara 181 hari sampai dengan 270 hari. Dan Macet 100\%, terjadi bila debitur tidak lagi membayar angsuran pokok dan bunga lebih dari 270 hari.

Adapun kebijakan penyaluran kredit yang diterapkan oleh PT Bank Rakyat Indonesia (Persero) Tbk Cabang Manado, yaitu membentuk memo analisa dengan menerapkan 5C, yaitu Character, menilai calon debitur dari latar belakangnya dan dari usaha yang dijalani. Capacity, menilai calon debitur dalam menjalankan usahanya dan kemampuan debitur dalam memenuhi kewajibannya. Condition, prinsip ini berkaitan dengan ekonomi makro dan mikro. 
Capital, menilai permodalan dan junlah asset yang dimiliki calon debitur. Collateral, menganalisis nilai jaminan yang dapat diberikan calon debitur kepada pihak bank.

Tentunya piutang tak tertagih pada PT Bank Rakyat Indonesia (Persero) Tbk Cabang Manado memiliki dampak, yaitu semakin besar piutang-piutang tak tertagih, pencadangan akan semakin besar. Dan semakin besar pencadangan hal itu akan menimbulkan kerugian pada pihak bank. Dampak yang juga terjadi terhadap laporan keuangan, yaitu pada laporan laba/ rugi dimana semakin tinggi piutang yang disalurkan tak tertagih, pencadangannya semakin besar otomatis terjadi kerugian dan penurunan kualitas pinjaman pada perusahaan. Dan laporan neraca, yaitu pada neraca off balance sheet dan neraca on balance sheet. Neraca off balance sheet mencatat piutang tak tertagih yang sudah dilakukan penghapusan bukuan tapi belum dihapus penagihannya. Sedangkan neraca on balance sheet mencatat piutang tak tertagih yang belum dihapus buku dan belum dihapus penagihannya.

\section{KESIMPULAN DAN SARAN}

\subsection{Kesimpulan}

Kesimpulan berdasarkan hasil penelitian ini adalah :

1. PT Bank Rakyat Indonesia (Persero) Tbk Cabang Manado menggunakan perhitungan menggunakan estimasi pembentukan PPAP atau metode cadangan kerugian piutang dengan memperkirakan piutang tak tertagih dari semua pemberian kredit yang beredar untuk menentukan besarnya kerugian piutang. Dan untuk pencatatannya, piutang tak tertagih kemudian dicatat dalam jurnal penyesesuaian. Setelah itu di sajikan dalam laporan keuangan PT Bank Rakyat Indonesia (Persero) Tbk Cabang Manado, yaitu pertama piutang tak tertagih disajikan pada laporan neraca (on balance sheet) apabila masih dicatat dalam pembukuan dan masih ditagih. Penyajian kedua akan disajikan pada laporan neraca off balance sheet apabila piutang tak tertagih sudah hapus buku tapi belum hapus tagih.

2. Kebijakan piutang tak tertagih yang dilakukan PT Bank Rakyat Indonesia (Persero) Tbk Cabang Manado menerapkan penggolongan kualitas kredit, yaitu Lancar sebesar 1\% yang tidak terdapat tunggakan, Dalam Perhatian Khusus sebesar 5\% tunggakannya sampai dengan 90 hari, Kurang Lancar sebesar 15\% tunggakannya 91 hari sampai dengan 180 hari, Diragukan 50\% tunggakannya 181 hari sampai dengan 270 hari, dan Macet 100\% tunggakan lebih dari 270 hari. Dan pihak bank menerapkan kebijakan menggunakan memo analisis 5C untuk melihat kualitas kelayakan seorang pemohon kredit yang ditentukan perusahaan.

3. Laporan keuangan merupakan hasil akhir dari perhitungan piutang tak tertagih pada PT. Bankng Rakyat Indonesia (Persero) Tbk Cabang Manado, dimana piutang tak tertagih akan berdampak pada laporan laba/rugi dan neraca. Selain itu, bank dapat mengetahui besarnya beban piutang tak tertagih dan besarnya cadangan umur piutang tak tertagih.

\subsection{Saran}

1. Penerapan menggunakan metode cadangan kerugian piutang terhadap piutang tak tertagih diharapkan terus konsisten diterapkan. Karena metode ini dapat mengetahui besarnya kredit yang diberikan dan menentukan besarnya penyisihan piutang tak tertagih berdasarkan klasifikasi pinjaman. Perhitungan ini lebih teliti dan efektif untuk mengetahui besarnya piutang sesuai dengan realisasinya.

2. Dalam pemberian kredit kepada nasabah, meskipun sudah menerapkan penggolongan kualitas kredit, sebaiknya PT Bank Rakyat Indonesia (Persero) Tbk Cabang Manado tidak lupa mempertimbangkan pemberian kredit yang diketahui secara umum. Dan pihak bank harus lebih pro aktif kepada nasabah untuk menghindari keterlambatan penyetoran kredit untuk menghindari masalah piutang tak tertagih 


\section{DAFTAR PUSTAKA}

Fahmi, I. (2016). Pengantar Manajemen Keuangan Teori dan Soal Jawab. Bandung: Alfabet.

Demak, Y.K., Tinangon, J. J., \& Mawikere, L.. (2018). Analisis piutang tak tertagih berdasarkan umur piutang pada PT. Air Manado. Jurnal Riset Akuntansi Going Concern, 13(4), 347-355.

Hery. (2013). Cara Mudah Memahami Akuntansi (Inti Sari Konsep Dasar Akuntansi). Jakarta : Prenada Media Group.

Hery. (2014). Akuntansi Aset, Liabilitas, dan Ekuitas. Jakarta : PT. Gasindo.

Ikatan Akuntansi Indonesia. (2015). PSAK No. 1 Tentang Laporan Keuangan, Edisi revisi 2015. Jakarta: PT. Raja Grafindo.

Junita, S., \& Khairani, S. (2012). Analisis kinerja perusahaan dengan menggunakan analisa rasio keuangan pada perusahaan telekomunikasi yang terdaftar di Bursa Efek Indonesia. Tugas Akhir. STIE MDP. Palembang.

Kartikahadi, H., Sinaga, R. U., Syamsul, M., \& Siregar, S. V. (2016). Akuntansi Keuangan Berdasarkan SAK Berbasis IFRS Buku 1. Jakarta : Salemba Empat.

Kasmir. (2013). Bank dan Lembaga Keuangan Lainnya. Jakarta : PT. Raja Grafind Persada.

Mardiasmo. (2016). Perpajakan Edisi Revisi Tahun 2016. Yogyakarta : Penerbit Andi.

Pontoh, W. (2013). Akuntansi Konsep dan Aplikasi. Jakarta : Halaman Moeka.

Pujiyanti, F. (2015). Akuntansi Dasar. Tangerang : Lembar Pustaka Indonesia.

Rivai, V., Basir, S., Sudarto, S., \& Vaithzal, A. P. (2013). Commercial Bank Management : Manajemen Perbankan dari Teori Ke Praktik, Edisi 1. Jakarta : Rajawali Pers.

Sumarauw, R. D. F., \& Gerungai, N. Y. T. (2018). IPTEKS Pengajuan Kredit Berdasarkan Informasi Akuntansi Pemberian Kredit Pada PT Bank Mandiri (Persero) Tbk. Area Manado. Jurnal Ipteks Akuntansi Bagi Masyarakat, 02(2), 294-299. https://doi.org/10.32400/jiam.2.02.2018.21747

Undang-undang No. 10 Tahun 1998. Tentang Perbankan Dan Booklet Perbankan Indonesia.

Weygant, J. J., Kimmel, P. D., \& Kieso, D. E.. (2015). Financial Accounting IFRS Edition. $3^{\text {rd }}$ ed. USA : Wiley. 